\title{
Comparative Study of Litter Quality, Decay Rates and Nutrient Fluxes of Invasive Species, Austroeupatorium inulifolium and Cymbopogon nardus
}

\author{
Piyasinghe I. ${ }^{*}$, Gunatilake G. ${ }^{2}$ and Madawala H.M.S.P. ${ }^{3}$ \\ ${ }^{1}$ Postgraduate Institute of Science, University of Peradeniya, Peradeniya, Sri Lanka \\ ${ }^{2}$ Department of Geology, Faculty of Science, University of Peradeniya, Peradeniya, Sri Lanka \\ ${ }^{3}$ Department of Botany, Faculty of Science, University of Peradeniya, Peradeniya, Sri Lanka \\ ipkpiyasinghe@yahoo.com
}

\begin{abstract}
Invasion of alien species into new habitats poses serious threats to their vegetation and ecosystem processes. Austroeupatorium inulifolium, an invasive species, has been rapidly invading degraded grasslands dominated by Cymbopogon nardus, another invasive, in the Knuckles Conservation Area (KCA). Invasive plants with rapid growth rates and elevated leaf nutrient concentrations could alter decomposition process and nutrient release patterns. This study was aimed at studying the litter quality, decay rates and nutrient release patterns of Austroeupatorium and Cymbopogon. In situ litterbag experiment was conducted in less and highly invaded grasslands at KCA. Surface litter and standing litter (above-ground) also have been quantified to assess the contribution of $\mathrm{C} 3$ and $\mathrm{C} 4$ plants to soil nutrient pool.

Litterbags $(\mathrm{n}=40)$ were prepared with air-dried litter samples of Austroeupatorium and Cymbopogon and were distributed in highly-invaded (HIG) and less invaded (LIG) sites (by Austroeupatorium). Litterbags were collected at different time intervals and chemically analysed. The decomposition rate was calculated using loss of litter biomass. The surface litter was estimated using randomly placed quadrates $\left(0.0625 \mathrm{~cm}^{2}\right)$. Standing litter biomass was quantified by clipping quadrates $\left(0.25 \mathrm{~m}^{2}\right)$ to the ground level. Contributions to aboveground litterfall by $\mathrm{C} 3$ and $\mathrm{C} 4$ plants were assessed. The results were statistically analysed and compared using Minitab 14.0.
\end{abstract}

Higher mass loss was observed with Austroeupatorium litter than that of Cymbopogon in both less and highly invaded habitats. Austrosupatorium litter quality (in terms of N and P) is higher than that of Cymbopogon. Leaf litter of Austroeupatorium showed significantly lower $\mathrm{C}: \mathrm{N}$ and $\mathrm{C}: \mathrm{P}$ ratios compared to Cymbopogon. Nitrogen and phosphorus release patterns during decomposition found to be slow in both Austroeupatorium and Cymbopogon irrespective of their habitats. Austroeupatorium showed relatively higher decomposition rate throughout the study period compared to Cymbopogon. The surface litter and standing litter biomasses were significantly higher in HIG compared to LIG. In both habitats, C3 plants contributed more to the standing litter biomass than that of $\mathrm{C} 4$ plants. Austroeupatorium plants contributed more to the total C3 biomass in both LIG and HIG.

The present results suggest that due to higher quality and decomposition rates of Austroeupatorium litter, the invasion may leads to changes in the soil nutrient pools and also their cycling processes. Long-term soil studies need to be carried out in order to investigate these findings further.

Keywords: Austroeupatorium, Knuckles conservation area, Litter decomposition, C3 and C4 plants

Proceedings of the International Forestry and Environment Symposium 2013 of the Department of Forestry and Environmental Science, University of Sri Jayewardenepura, Sri Lanka. 